\title{
Monoterpene hydrocarbons, major components of the dried leaves essential oils of five species of the genus Eucalyptus from Côte d'Ivoire
}

\author{
Kanko Coffi ${ }^{1^{*}}$, Koné Soleymane ${ }^{2}$, Ramiarantsoa Harisolo ${ }^{1}$, Tue Bi Balo², \\ Chalchat Jean Claude ${ }^{3}$, Chalard Pierre ${ }^{3}$, Figueredo Gilles ${ }^{3}$, Ahibo-Coffy Antoine $^{1}$ \\ ${ }^{1}$ Laboratoire de Chimie Organique Biologique, Unité de Formation et de Recherche des Sciences des Structures de la Matière et de \\ Tecnhologie (UFR SSMT), Université de Cocody-Abidjan, Abidjan, Côte d'Ivoire; ${ }^{*}$ Corresponding Author: kankoffi@yahoo.fr \\ ${ }^{2}$ Laboratoire de Chimie Organique Structurale, UFR SSMT, Université de Cocody-Abidjan, Abidjan, Côte d'Ivoire \\ ${ }^{3}$ Laboratoire de Chimie des Hétérocycles et des Glucides Chimie des Huiles Essentielles, Université Blaise Pascal, Clermont Ferrand, \\ France
}

Received 30 July 2011; revised 31 August 2011; accepted 10 September 2011

\begin{abstract}
The chemical composition of the essential oils obtained from the dried leaves of five species of the genus Eucalyptus (E. camaldulensis, E. deglupta, E. grandis, E. torelliana, E. urophylla) growing in Côte d'Ivoire, was analyzed by means of GC and GC/MS. The density and the refractive index were measured. The major components of all these oils are: $\alpha$-pinene, $\beta$-pinene, $\alpha$-phellandrene, limonene, $\gamma$-terpinene, $p$-cymene and $\beta$-caryophyllene. The particularity of these oils is their monoterpene hydrocarbons major components.
\end{abstract}

Keywords: Eucalyptus camaldulensis; E. deglupta; E. grandis; E. torelliana; E. urophylla; Essential Oil; Monoterpene Hydrocarbons; Density; Refractive Index

\section{INTRODUCTION}

The genus Eucalyptus is native from Australia but it is presently spread all over the word. It is one of the Myrtaceae family which comprises about 800 species [1]. Experimental plantations of Eucalyptus were setting up nearly Abidjan (Côte d'Ivoire). The essential oils of some of these species have been widely studied. The genus Eucalyptus essential oils are widely used all over the word as spices, flavors, perfumes industrial raw materials and pharmaceutical [2]. Kambu et al. have reported the insecticidal and carminative properties of the essential oil of some Eucalyptus species [3]. Others Eucalyptus essential oils have been reported to reveal antimicrobial properties $[4,5]$. Eucalyptus deglupta Blume is a huge evergreen tree of up to 60 (max. 75) m tall; bole generally of good form; $50 \%-70 \%$ of the tree height, up to $240 \mathrm{~cm}$ in diameter.
E. deglupta is used to a limited extent for firewood and charcoal. However, it is normally considered too valuable for firewood. Eucalyptus grandis W. Hill ex Maiden (flooded gum) is a fast growing, tall to very tall straight-trunked tree. The specie has been widely planted for paper pulp, poles and sawn timber [6]. Eucalyptus urophylla is a medium-sized to tall tree reaching $35-55 \mathrm{~m}$ in height, with a straight bole, up to $200 \mathrm{~cm}$ in diameter. Eucalyptus torelliana, F. Muell is native of rainforest and rainforest margins in northern Queensland. Tree is up to $30 \mathrm{~m}$ high. Eucalyptus camaldulensis Dehnh is one the smallest trees (5 - $20 \mathrm{~m}$ high) of the genus Eucalyptus with bark smooth, white, powdered [6]. Camara et al. have revealed an antifungal activity of the dried leaves essential oil of Eucalyptus platyphylla against Deightoniella torulosa, the banana plantain leaves fungi [7]. Eucalyptus camaldulensis oil, rich in 1,8-cineole, has been widely studied throughout the word [8-13]. The essential oils of Eucalyptus deglupta, Eucalyptus grandis, Eucalyptus urophylla and Eucalyptus torelliana are less studied. Eucalyptus torelliana from Benin was found to contain $\alpha$-pinene (18\%), (14\%) and spathulenol (16\%) [14]. It was also reported that $\alpha$-pinene (50\%) was the major constituent of a sample of $E u$ calyptus torelliana oil from Mali [15]. From Congo-Brazzaville Loumouamou et al. have reported a very rich $\alpha$-pinene $(78 \%, 1 \%)$ sample of E. torelliana [16]. From Brazilian Cerrado the major components of the oil of $E$. grandis are p-cymene $(14 \%, 5 \%)$, isoleptopermone $(13 \%$, $2 \%$ ) 1,8-cineole (5\%, 5\%) [17]. Jeane Silva et al. have reported an analgesic and anti-inflammatory effects of a Brazilian sample of $E$. grandis essential oil rich in monoterpenic hydrocarbons ( $\alpha$-pinene, $\gamma$-terpinene), p-cymene) [12]. The Marocco oil was found to contain p-cymene (23\%, 2\%), 1,8-cineole $(20 \%, 43 \%)$ and $\alpha$-pinene $(14 \%$, 74\%) [13]. The Nigerian E. grandis oil contained a-pinene $(30 \%, 4 \%)$, terpinen- 4 -ol $(10 \%, 7 \%)$, E- $\beta$-ocimene $(9 \%$, 
$4 \%)$, borneol $(8 \%, 4 \%)$ and $\alpha$-terpineol $(8.0 \%)$ [1]. The major components of E. grandis and E. urophylla oils from Ethiopia were respectively $\alpha$-pinene $(44 \%, 7 \%), \alpha$ pinene $(30 \%, 5 \%)$ and, limonene $(9 \%, 8 \%), \beta$-pinene $(9 \%, 1 \%)$ [19]. The Brazilian Cerrado E. urophylla essential oil contained 1,8 -cineole $(44 \%, 7 \%), \alpha$-pinene $(15 \%$, $6 \%), \alpha$-terpenyl acetate $(11 \%, 7 \%)$ [17] Cimanga et al. have reported the chemical composition of the essential oils of E. deglupta and E. urophylla from the Democratic Republic of Congo. The major components of $E$. deglupta and E. urophylla are respectively 1,8-cineole $(35 \%, 7 \%)$, cryptone $(25 \%, 4 \%)$ and 1,8 -cineole $(57 \%$, $7 \%), \alpha$-pinene $(10 \%, 1 \%)[11]$.

As part of our on-going research on the essential oils of the medicinal and aromatic plants from Côte d'Ivoire, the present investigation concern the detailed analyses of the leaf oils of E. camaldulensis, E. deglupta, E. grandis, E. torelliana and E. urophylla in order to compare them to other studies reported for the same species from various parts of the world. To the best of our knowledge, the oils of E. camaldulensis, E. deglupta and E. urophylla with monoterpenes hydrocarbons as major components have not been reported previously.

\section{EXPERIMENTAL}

Plant material: The leaves of E. deglupta, E. torellia$n a$ and $E$. urophylla were collected from the campus of University of Cocody-Abidjan. E. camaldulensis, and E. grandis leaves were collected from the Sodefor plantations near Abidjan.

Oil isolation: Leaves collected were dried for one week and $200 \mathrm{~g}$ of each dried leaf were submitted to hydrodistillation with Clevenger apparatus for $3 \mathrm{~h}$. Refractive index and density were determined respectively with CONVEX and APPAR DMA 45 apparatus.

Analysis: The essential oil samples were analyzed by gas chromatography and gas chromatography/mass spectrometry.

GC: Analyses were carried out on a Delsi DI200 apparatus using the following conditions D8-5 column $(25 \mathrm{~m}$ $\times 0.25 \mathrm{~mm}, 0.25 \mathrm{~mm}$ film thickness); flame ionization detector, Split: $60 \mathrm{~mL} / \mathrm{min}, \mathrm{N}_{2}$ as carrier, temperature program: $50^{\circ} \mathrm{C}-220^{\circ} \mathrm{C}$, rate: $3^{\circ} \mathrm{C} / \mathrm{min}$, injector and detector temperatures : $220^{\circ} \mathrm{C}$ and $235^{\circ} \mathrm{C}$, respectively.

GC/MS: Analyses were carried out on Hewlett-Packard gas chromatograph, Model 6890 in following conditions: HP5 column $(30 \mathrm{~m} \times 0.25 \mathrm{~mm}, 0.25 \mathrm{~mm}$ film thickness); carrier gas: He, injection in Split mode (1/10); injector and detector temperatures: $250^{\circ} \mathrm{C}$ and $320^{\circ} \mathrm{C}$, respectively. The MS was used in the electron impact mode $(70 \mathrm{eV})$, ion temperature source: $230^{\circ} \mathrm{C}$, mass scan mode, $\mathrm{m} / \mathrm{z}$ : 33 - 450, The identification was carried out by the calculation of Retention Index (RI) using n-alkenes and a comparison with available mass spectral data [20,21].

\section{RESULTS AND DISCUSSION}

The oil yield and physic-chemical characteristics of the five Eucalyptus species are reported in Table 1. The essential oils yields vary from $0.20 \%$ to $0.70 \%$. The refraction indices and the densities observed were in conformity with those usually observed for oils of Eucalyptus in the literature [7]. Table 2 shows the composition as single components present in the five species of Eucalyptus.

Table 1. Oil yield and physic-chemical characteristics of Eucalyptus studied species.

\begin{tabular}{lccc}
\hline Species & Yield (\%) & Refractive indexes & density \\
\hline E. camaldulensis & 0.70 & 1.4819 & 0.8646 \\
E. deglupta & 0.70 & 1.4609 & 0.8741 \\
E. grandis & 0.54 & 1.4805 & 0.8717 \\
E. torelliana & 0.20 & 1.4605 & 0.8681 \\
E. urophylla & 0.40 & 1.4811 & 0.8750 \\
\hline
\end{tabular}

Table 2. Chemical composition of essential oils from the five Eucalyptus studied.

\begin{tabular}{|c|c|c|c|c|c|c|}
\hline Components & RI & E. urophyla & E. torelliana & E. deglupta & E camaldulensis & E. grandis \\
\hline$\alpha$-thujene & 928 & 0.65 & 0.43 & 3.09 & 1.58 & 1.09 \\
\hline$\alpha$-pinene & 935 & 6.98 & 42.85 & 0.82 & 8.04 & 37.84 \\
\hline fenchene & 950 & 0.07 & & & & \\
\hline camphene & 952 & 0.22 & & & 0.11 & \\
\hline benzaldehyde & 965 & & 0.26 & & & \\
\hline sabinene & 975 & & & 0.10 & & \\
\hline$\beta$-pinene & 980 & 14.90 & 7.11 & & 28.92 & 15.53 \\
\hline myrcene & 991 & 0.63 & 0,22 & 0.69 & 1.00 & \\
\hline$\alpha$-phellandrene & 1008 & 8.89 & 0.19 & 42.25 & 19.65 & 0.96 \\
\hline$\alpha$-terpinene & 1019 & 0.40 & & 0.61 & 0.55 & 0.18 \\
\hline para cymene & 1027 & 17.38 & & 20.95 & 9.56 & 5.24 \\
\hline limonene & 1032 & 2.77 & 2.52 & 0.97 & 2.68 & 5.98 \\
\hline$\beta$-phellandrene & 1033 & 0.66 & & 2.36 & 1.63 & \\
\hline $\operatorname{cis} \beta$-ocimene & 1038 & & 0.66 & & & \\
\hline
\end{tabular}




\section{Continued}

\begin{tabular}{|c|c|c|c|c|c|c|}
\hline trans $\beta$-ocimène & 1049 & & 0.18 & & 0.05 & \\
\hline$\gamma$-terpinene & 1062 & 22.66 & 0.18 & 8.12 & 7.90 & 0.37 \\
\hline cis linalool oxyde & 1073 & & & 0.12 & 0.09 & \\
\hline terpinolene & 1087 & 0.90 & 0.46 & 0.94 & 0.92 & 0.26 \\
\hline 2-nonanone & 1092 & 0.17 & & 0.18 & 0.12 & \\
\hline linalool & 1101 & & 0.21 & 0.10 & 0.10 & 0.18 \\
\hline$\alpha$-fenchol & 1123 & 0.35 & & & 0.17 & \\
\hline cis para menth-2-en-1-ol & 1128 & & & 0.29 & 0.11 & \\
\hline$\alpha$-campholenal & 1130 & & & & & 0.10 \\
\hline trans para menth-2-en-1-ol & 1145 & 0.08 & & 0.22 & 0.14 & 0.14 \\
\hline citronellal & 1155 & & & & & 0.09 \\
\hline$\delta$-terpinéol & 1174 & 0.10 & & 0.26 & & \\
\hline borneol & 1176 & 0.52 & & 0.29 & 0.17 & \\
\hline 1,8-menthadien-4-ol & 1182 & 0.32 & & 0.12 & 0.36 & \\
\hline terpinen-4-ol & 1184 & 3.06 & 0.11 & 2.89 & 1.96 & 0.33 \\
\hline cis mentha-1(7),8-dien-2-ol & 1190 & 0.11 & & 0.25 & 0.10 & \\
\hline$\alpha$-terpineol & 1199 & 2.62 & 0.89 & 0.23 & 1.81 & 0.89 \\
\hline verbenone & 1207 & 0.23 & & 1.11 & 0.56 & 0.20 \\
\hline trans carveol & 1222 & & & & 0.09 & \\
\hline trans mentha-1(7),8-dien-2-ol & 1233 & & & & & 0.36 \\
\hline$\alpha$-phellandrene epoxyde & 1244 & 0.09 & & 0.30 & & 1.15 \\
\hline carvotanacetone & 1251 & & & & 0.13 & \\
\hline carvotanacetone & 1253 & 0.08 & & 0.16 & 0.13 & 0.62 \\
\hline piperitone & 1258 & & & & & \\
\hline safrole & 1293 & 1.30 & & 0.30 & & 1.00 \\
\hline carvacrol & 1300 & 0.18 & & 0.47 & 0.19 & 0.78 \\
\hline eugenol & 1354 & 0.63 & & & & \\
\hline isoledene & 1375 & & 0.1 & & & \\
\hline$\alpha$-copaene & 1380 & 0.19 & 0.26 & & 0.09 & \\
\hline méthyl eugenol & 1401 & 0.10 & & 0.15 & & \\
\hline$\alpha$-gurjunene & 1412 & 0.12 & 0.49 & 0.25 & 0.17 & 0.13 \\
\hline$\beta$-maaliene & 1418 & & 0.14 & & & \\
\hline$\beta$-caryophyllene & 1425 & 2.04 & 14.54 & & 1.54 & 5.02 \\
\hline$\gamma$-maaliene & 1433 & & 0.24 & & & \\
\hline$\beta$-gurjunene & 1436 & 0.06 & 0.18 & 0.10 & 0.10 & \\
\hline$\beta$-maalienene & 1440 & 0.50 & 0.26 & & & \\
\hline cubeb-11-ene & 1444 & & 4.16 & 3.12 & 0.53 & 1.96 \\
\hline sélina-5,11-diene & 1451 & & 1.78 & 0.06 & & 0.09 \\
\hline$\alpha$-humulene & 1461 & 0.40 & 1.49 & 0.12 & 0.25 & 0.63 \\
\hline allo-aromadendrene & 1466 & 0.17 & 1.07 & 0.55 & 0.16 & 0.23 \\
\hline$\gamma$-gurjunene & 1478 & 0.07 & 0.42 & 0.14 & & 0.19 \\
\hline$\delta$-sélinene & 1491 & & 0.26 & & & \\
\hline viridoflorene & 1495 & 0.33 & 2.03 & 0.57 & 0.17 & 1.08 \\
\hline$\alpha$-muurolène & 1501 & 0.19 & 2.39 & 0.29 & 0.08 & 0.20 \\
\hline$\gamma$-cadinene & 1518 & & 0.07 & 0.07 & & 0.32 \\
\hline$\delta$-cadinene & 1522 & 0.14 & 0.43 & 0.18 & 0.13 & \\
\hline viridoflorol & 1568 & 0.05 & 0.29 & 0.49 & & \\
\hline ledol & 1576 & & 0.27 & 0.16 & & \\
\hline spathulenol & 1582 & 0.10 & 0.60 & 1.05 & & 4.28 \\
\hline oxyde de caryophillene & 1588 & 0.17 & 0.77 & 0.10 & 0.15 & 3.25 \\
\hline globulol & 1592 & 0.26 & 1.47 & 2.26 & 0.27 & 0.27 \\
\hline guaiol & 1601 & 0.12 & 3.86 & 0.38 & 0.10 & 0.37 \\
\hline$\gamma$-eudemol & 1638 & 4.04 & 0.15 & 0.09 & 1.64 & 0.64 \\
\hline hinesol & 1640 & 0.30 & & & 0.18 & \\
\hline apia-cadinol & 1646 & 0.47 & 1.86 & & 0.19 & \\
\hline$\alpha$-eudesmol & 1661 & & 0.58 & & 4.46 & 0.18 \\
\hline$\beta$-eudesmol & 1663 & 0.45 & & 0.11 & & \\
\hline NJ & 1801 & 0.18 & & 0.13 & 0.17 & 0.20 \\
\hline TOTAL & & 98.86 & 97.17 & 99.22 & 99.65 & 92.92 \\
\hline
\end{tabular}


Eucalyptus camaldulensis oil was found to contain 43 constituents with individual contents $\geq 0.1 \%$. The major constituents were $\beta$-pinene $(28 \%, 92 \%)$ and $\alpha$-phellandrene $(19 \%, 65 \%)$ followed by para-cymene $(9 \%, 56 \%)$, $\alpha$-pinene $(8 \%, 0.4 \%), \gamma$-terpinene $(7 \%, 9 \%)$. These results are different with those of the previous studies on the chemical type of E. camaldulensis from Argentina [11], Australia [18], Marocco [14], Mozambique [9], Côte d'Ivoire [10], Ethiopia [19] and Democratic Republic of Congo [12]. Eucalyptus torelliana oil was also found to contain 41 constituents. The major constituent is $\alpha$-pinene ( $42 \%$,
$85 \%)$ followed by $\beta$-caryophyllene $(14 \%, 5 \%)$ and $\beta$ pinene $(7 \%, 11 \%)$. Forty four constituents were identified in E. urophyla oil. The major constituents of this oil were $\gamma$-terpinene $(22 \%, 7 \%)$, para-cymene $(17 \%, 4 \%), \beta$-pinene $(14 \%, 9 \%), \alpha$-phellandrene $(8 \%, 89 \%)$ and $\alpha$-pinene $(6 \%$, $98 \%)$, From $E$. grandis oil we have identify 37 constituents. The main major constituents of $E$. grandis oil are $\alpha$-pinene $(37 \%, 84 \%), \beta$-pinene $(15 \%, 53 \%)$ followed by limonene $(5 \%, 98 \%)$ and para-cymene $(5 \%, 24 \%)$. Forty six constituents were identified in E. deglupta essential oil with three major constituents: $\alpha$-phellandrene $(42 \%, 25 \%)$,

Table 3. Major constituents of E. deglupta, E urophylla and E. torelliana essential oils samples.

\begin{tabular}{|c|c|c|c|c|c|c|c|c|c|c|}
\hline \multirow[b]{2}{*}{ Composés } & \multicolumn{2}{|c|}{ E. deglupta } & \multicolumn{4}{|c|}{ E. urophylla } & \multicolumn{4}{|c|}{ E. torelliana } \\
\hline & DRC & C.I. & DRC & Braz 2 & Ethi & C.I. & Congo 1 & Congo 2 & Congo 3 & C.I. \\
\hline$\alpha$-pinène & & & 10.1 & 15.6 & 13.3 & 6.98 & 78.1 & 20.3 & & 42.85 \\
\hline$\beta$-pinène & & & & & 9.1 & 14.9 & 7.9 & & & 7.11 \\
\hline$\alpha$-phellandrène & 7.2 & 42.25 & & & & 8.89 & & & & \\
\hline$\gamma$-terpinène & & 8.12 & & & & 22.7 & & & & \\
\hline para cymène & & 20.95 & & & & 17.4 & & & & \\
\hline Limonène & & & 6.4 & & 9.8 & & & & & \\
\hline 1,8-cinéole & 35.7 & & 57.7 & 44.7 & 34.5 & & & & & \\
\hline cryptone & 25.4 & & & & & & & & & \\
\hline$\beta$-caryophyllene & & & & & & & & 5.8 & & 14.5 \\
\hline$\alpha$-terpenyl acetate & & & & 11.7 & 11.6 & & & & & \\
\hline Citronellyl acetate & & & & & & & & & 56.5 & \\
\hline aromadendrene & & & & & & & & 6.4 & & \\
\hline Myrténol & 7.4 & & & & & & & & & \\
\hline globulol & & & & & & & & 17.5 & & \\
\hline TOTAL & 75.7 & 71.32 & 74.2 & 72 & 78.3 & 70.8 & 86 & 50. & 56.5 & 64.5 \\
\hline
\end{tabular}

N.B.: DRC: Democratic Republic of Congo; Braz: Brazil ; Ethi; Ethiopia; CI: Côte d'Ivoire.

Table 4. Major constituents of E. camaldulensis and E. grandis essential oils samples.

\begin{tabular}{|c|c|c|c|c|c|c|c|c|c|c|c|}
\hline \multirow[b]{2}{*}{ Components } & \multicolumn{8}{|c|}{ Eucalyptus camaldulensis } & \multicolumn{3}{|c|}{ E. grandis } \\
\hline & Argent & Austr 1 & Austr 2 & Maroc & Moz & C.I. (1) & $\mathrm{RDC}$ & C.I. (2) & Bresil & Maroc & C.I. \\
\hline$\alpha$-pinene & & 14.89 & & 11.23 & 5.5 & 16.7 & 5.4 & 8.04 & 40.55 & 14.64 & 37.84 \\
\hline$\beta$-pinene & & & & & & & & 28.92 & & & 15.53 \\
\hline$\alpha$-phellandrene & 6.45 & & & & & & & 19.65 & & & \\
\hline$\gamma$-terpinene & & & & & & & & 7.9 & 16.25 & & \\
\hline para cymene & 17.93 & & 12.36 & 11.24 & 5.2 & & & 9.56 & 13.13 & 23.2 & \\
\hline Limonene & & 7.27 & & & & & 5.4 & & & & 5.98 \\
\hline 1,8 -cineole & 19.3 & 66.19 & & 50.69 & 43.4 & 12.9 & 58.9 & & & 20.43 & \\
\hline$\beta$-Phéllandrene & 16.34 & & & & & & & & & & \\
\hline Terpineol-4 & 5.83 & & & & & & & & & & \\
\hline cryptone & 5.71 & & 9.81 & & & & & & & & \\
\hline$\alpha$-terpineol & & & & & & & & & & & \\
\hline Allo-aromadendrene & & & & & & 8.7 & & & & & \\
\hline Spathulenol & 6.83 & & 28.97 & 4.9 & & & & & & & \\
\hline trans-Pinocarvol & & & & & & & & & & 6.64 & \\
\hline Globulol & & & & & & 10.4 & & & & 5.34 & \\
\hline TOTAL & 78.39 & 88.35 & 55.75 & 78.06 & 54.1 & 48.7 & 69.7 & 74.07 & 70.38 & 70.25 & 64.59 \\
\hline
\end{tabular}

N.B: Argent: Argentina; Austr: Australia; Moz: Mozambica; Maroc: Marocco. 
para-cymene $(20 \%, 95 \%), \gamma$-terpinene $(8 \%, 12 \%)$.

In this study $\alpha$-pinene and $\beta$-pinene was found in $E$. grandis and E. torelliana as the major components. As shown in Table 3 and Table 4, the main constituents of $E$. grandis and E. torelliana essential oils were similar to that of the same species investigated respectively by Dagne et al. from Ethiopia [19], Loumouamou et al. from CongoBrazzaville [17]. In Table 3, $\alpha$-pinene is one the main components who is present in the samples from Brazil $(40 \%$, $55 \%$; 24\%, 7\%), Morocco (14\%, 64\%), Nigeria (30\%, 4\%) and Ethiopia $(44 \%, 7 \%)$. However, there is predominance of monoterpene hydrocarbons in the essential oils of $E$ camaldulensis, E. urophyla and E. deglupta from Côte d'Ivoire while oxygenated monoterpenoids were in abundance in the samples of E. camaldulensis from Argentina, Australia, Morocco, Mozambique, Côte d'Ivoire, Ethiopia, Democratic Republic of Congo. The oxygenated monoterpenoids were also in abundance in the essential oils of E. deglupta from Democratic Republic of Congo and E. urophyla from Democratic Republic of Congo, Brazil, Ethiopia.

\section{REFERENCES}

[1] Ogunwande, A.I., Olawore, N.O., Adeleke, A.K. and Konig, A.W. (2003) Chemical composition of the essential oils the leaves of three Eucalyptus species growing in Nigeria. Journal of Essential Oil Research, 15, 297-301.

[2] Dellacassa, E., Menedez, P. and Moyna, P. (1990) Chemical composition of Eucalyptus essential oils grown in Uruguay. Flavour and Fragrance Journal, 5, 91-95.

[3] Kambu, K., Phanzu, N., Coune, C. and Wanters, J.N. (1982) Contribution to the insecticidal and chemical properties of Eucalyptus saligna from Zaire. Plantes Médicinales et Phytothérapie, 16, 34-38.

[4] Dellacassa, E., Menedez, P., Moyna, P. and Caldeiras, P. (1989) Antimicrobial activity of Eucalyptus essential oil, Fitoterapia, 60, 544-546.

[5] Oyedeji, A.O., Ekundayo, O., Olawore, O.N., Adeniyi, B.A. and Koenig, W.A. (1999) Antimicrobial activity of essential oils of five Eucalyptus species growing in Nigeria. Fitoterapia, 70, 526-528. doi:10.1016/S0367-326X(99)00083-0

[6] Boland, D.J., Brophy, J.J. and House, P.N. (1991) Eucalyptus leaf oils, use, chemistry, distillation and maeketing. Inkata Press, Melbourne.

[7] Camara, B., Dick, E., Sako, A., Kone, D., Kanko, C., Boye, M.-A.-D., Ake, S. and Anno, A. (2010) Lutte biologique contre Deightoniella torulosa (Syd.) Ellis, par l'application des huiles essentielles d'Eucalyptus platyphylla $\mathrm{F}$. Muell. et de Melaleuca quinquenervia L. Phytotherapie, 8, 240-244.

[8] da Cruz Francisco, J., Jãrvenpãã, E.P., Huopalahti, R. and Sivik, B. (2001) Comparison of Eucalyptus camaldulensis Dehn. Oils from mozambique as obtained by hydrodistillation and supercritical carbon dioxide extraction.
Journal of Agricultural and Food Chemistry, 49, 23392342. doi:10.1021/jf0013611

[9] Tonzibo, Z.F. (1998) Contribution à l'étude des Huiles Essentielles des espèces acclimatées en Côte d'Ivoire: E. camaldulensis, $O$. gratissimum et $O$. basilicum. Thèse de 3è Cycle, Chimie Organique, Université de CocodyAbidjan.

[10] Lucia, A., Licastro, S., Zerba, E. and Masuh, H. (2008) Yield, chemical composition, and bioactivity of essential oils from 12 species of Eucalyptus on Aedes aegypti larvae. Entomologia Experimentalis et Applicata, 129, 107114.

[11] Cimanga, K., Kambu, K., Tona, L., Apers, S., De Bruyne, T., Hermans, N., Totte, J., Pieters, L. and Vlietinck, A.J. (2002) Correlation between chemical composition and antibacterial activity of essential oils of some aromatic medicinal plants growing in the Democratic Republic of Congo. Journal of Ethnopharmacology, 79, 213-220. doi:10.1016/S0378-8741(01)00384-1

[12] Abebe, J.S.W., Sousa, S.M., Duarte, V.G., Machado, M.I.L. and Matos, F.J.A. (2003) Analgesic and anti-inflammatory effects of essential oils of Eucalyptus. Journal of Ethnopharmacology, 89, 277-283. doi:10.1016/j.jep.2003.09.007

[13] Farah, A., Fechtal, M. and Chaouch, A. (2002) Effet de l'hybridation interspécifique sur la teneur et la composition chimique des huiles essentielles d'eucalyptus cultivés au Maroc. Biotechnology, Agronomy, Society and Environment, 6, 163-169.

[14] Sohounhloué, D.K., Dangou, J., Gnomhossou, B., Garneau, F.X., Gagnon, H. and Jean, F.I. (1996) Leaf oils of three Eucalyptus species from Benin: Eucalyptus torelliana F. Muell, E. citriodora Hook and E. tereticornis Smith. Journal of Essential Oil Research, 8, 111-113.

[15] Chalchat, J.C., Gary, R.Ph., Sidibé, L. and Harama, M. (2000) Aromatic plants of Mali (V): Chemical composition of four Eucalyptus species implanted in Mali, Eucalyptus camaldulensis, E. torelliana, E. citriodora, E. tereticornis. Journal of Essential Oil Research, 12, 695-701.

[16] Loumouamou, A.N., Silou, Th. and Mapola, G. (2009) Yield and Composition of essential oils From E. citriodora $\times$ E. torelliana a hybrid species growing in CongoBrazzaville. Journal of Essential Oil Research, 21, 295-299.

[17] De Olivera Flavia, N.M., Pedro, F.H., Paula, J.R., Seraphin, J.C. and Estefano, F.P. (2008) Seasonal influence on the essential oil compositions of Eucalyptus urophylla S. T Blake and E. grandis W Hill ex Maiden from Brazilian Cerrado. Journal of Essential Oil Research, 20, 555-560.

[18] Bignell, C.M., Dunlop, P.J., Brophy, J.J. and Jackson, J.F. (1996) Volatile leaf oils of some South-Western and Southern Australian species of the Genus Eucalyptus Part MI. A. Subgenus Eudesmia: B. Subgenus Symphyomyrtus: (a) Section Exsertaria; (b) Series Globulares. Flavour and Fragrance Journal, 11, 145-151.

doi:10.1002/(SICI)1099-1026(199605)11:3<145::AID-FF $\underline{\mathrm{J} 565>3.0 . \mathrm{CO} ; 2-\mathrm{O}}$

[19] Dagne, E., Bisrat, D., Alemayehu, M. and Worku, T. 
(2000) Essential oil of twelve eucalyptus species from ethiopia. Journal of Essential Oil Research, 12, 467-470.

[20] Adams, R.P. (1995) Identification of essential oil components by gas chromatography/mass spectroscopy. Allured Publ. Corp. Carol Stream IL.
[21] Mc Lafferty and Stauffer (1989) The Wiley NBS registry of mass spectral data. 2ème Edition, John Wiley and Sons, New York. 